\title{
THE RECONSTRUCTION OF ISLAMIC THEOLOGY IN THE UNITY OF SCIENCES
}

\author{
Yusriyah \\ Universitas Islam Negeri (UIN) Walisongo, Semarang \\ e-mail: yusriyahm@yahoo.com
}

\begin{abstract}
As a result of the processes of thinking on theological concept, Islamic theology may change according to its social dynamics. In the contemporary, theology can be studied by interdisciplinary sciences, which eventually theology became the source of the birth of some sciences. Hence, the science produced by the understanding of monotheism will produce peaceful religion for the universe (rahmatan li '1-'allamin). The data presented in this article derived from the study applying literature review on the related topics of writing. Applying qualitative approach, this article showed that religion and science have a point of tangency. Science helps to facilitate human beings in their religious living. Concerning to faith, science activities can strengthen the faith and arise the motivation to express something in recognizing more toward God as the center of unity of existence (tawhid). In order to integrate the belief and sciences, it is needed the effort of islamization of science and the effort to reconstruct theology into a format that make it possible to dialogue with the reality of current development of thinking.

Sebagai hasil dari pemikiran konsep teologis teologi Islam dapat berubah sesuai dengan dinamika sosial. Dalam era kontemporer teologi dapat dikaji oleh ilmu-ilmu interdisipliner, yang akhirnya teologi merupakan sumber lahirnya beberapa ilmu sehingga ilmu yang dihasilkan oleh pemahaman tawhïd akan menghasilkan agama damai bagi alam semesta (rahmatan li '-'âlamīn). Data yang disajikan dalam artikel ini berasal dari penelaahan terhadap literatur yang terkait dengan topik penulisan. Dengan pendekatan kualitatif artikel ini menunjukkan bahwa agama dan sains memiliki titik singgung. Ilmu membantu memfasilitasi manusia dalam kehidupan keagamaannya. Dengan iman, kegiatan ilmiah dapat memperkuat iman dan membuat motivasi untuk mengekspresikan sesuatu yang dapat menambah pengakuan terhadap Allah sebagai pusat kesatuan eksistensi (tawhīd). Untuk mewujudkan ketersinggungan antara iman dan ilmu maka perlu islamisasi ilmu pengetahuan dan juga dalam upaya untuk merekonstruksi teologi ke format yang dapat berdialog dengan realitas perkembangan pemikiran yang berlangsung hari ini.
\end{abstract}

Keywords: Islamic theology, reconstruction, unity of science, integration 


\section{A. Pendahuluan}

Menelusuri teologi klasik setidaknya ada dua persoalan yang menyertainya, yaitu teologi yang bercorak metafisis spekulatif, yang bersifat teosentris. ${ }^{1}$ Dan teologi yang berkaitan erat antara teologi dengan politik dalam mempertahankan status quo dan menjadi alat legitimasi. Sehingga pemikiran keagamaan pada masa itu cenderung kering, rigid, dan formal. ${ }^{2}$ Karena kuatnya dominasi kekuasaan dalam rumusan teologi Islam, dan juga adanya hegemoni ilmu pengetahuan menyebabkan hilangnya nilai-nilai substantif dari pemikiran ketuhanan, dan jauh dari nilai-nilai sosial dan kemanusiaan elastis yang bersifat dinamis.

Khazanah keilmuan model seperti inilah yang berabad-abad banyak melahirkan intelektual. Teologi direduksi sedemikian rupa sehingga menjadi kumpulan wacana spekulatif yang jauh dari persoalan hidup dan gerak sejarah, sehingga kerangka epistemologi keilmuan dalam Islam masih memisahkan antara teosentris dan antroposentris atau yang sering dimaknai dengan sekularisasi ilmu pengetahuan.

Era itu telah berlalu dan diskursus teologi sudah seharusnya mengikuti perkembangan pemikiran kontemporer, menjadi ilmu pejuang sosial, yang menjadikan keimanan memiliki fungsi secara aktual sebagai landasan etik manusia beragama. Kegelisahan inilah yang dirasakan Hassan Hanafi, ${ }^{3}$ dengan teologi revolusionernya. Bagi Hanafi pemikiran dalam teologi harus menjadi sesuatu yang bermanfaat bagi masa kini, yaitu dengan melakukan revisi dan rekonstruksi serta membangun kembali epistemologi lama menuju epistemologi baru yang lebih signifikan. Begitu juga yang dirasakan Muhammad Amin Abdullah dengan integrasi dan interkoneksinya dan sinergi Azumardi Azra, serta pohon ilmu oleh Imam Suprayogo. Semuanya masih menunjukkan bahwa ilmu pengetahuan merupakan sesuatu yang terpisah sehingga perlu didialogkan. 42.

${ }^{1}$ Madjid Fakhry, The History of Islamic Philosophy, (New York: Columbia University Press, 1983), h.

${ }^{2}$ Amin Abdullah, Islamic Studies di Perguruan Tinggi: Pendekatan Integratif-Interkonektif, (Yogyakarta: Pustaka Pelajar, 2010), h. 339 baca juga, Haryatmoko, Etika Politik dan Kekuasaan, (Jakarta: Kompas, 2003), h. 63.

${ }^{3}$ Kazuo Shimogaki, Kiri Islam Antara Modernisme dan Postmodernisme: Telaah Kritis Pemikiran Hassan Hanafi, (Yogyakarta: LKiS, 2001), h.132, baca juga E. Kamadiningrat, Teologi dan Pembebasan: Gagasan Islam Kiri Hassan Hanafi, (Jakarta: Logos, 1995), h. 63-64. 
Wacana islamisasi ilmu pengetahuan juga digagas oleh Naquib al-Attas, Ziauddin Sardar, Ismail Raji al-Faruqi dan Fazlur Rahman. Kemunculan ide islamisasi ilmu tersebut tidak lepas dari ketimpangan-ketimpangan yang merupakan akibat langsung keterpisahan antara sains dan agama. Sekularisme telah membuat sains sangat jauh dari kemungkinan untuk didekati melalui kajian agama. Isma'il Raji al-Faruqi, misalnya, melakukan upaya-upaya untuk mengembalikan ilmu pengetahuan pada pusatnya yaitu tawhïd. Hal ini dimaksudkan agar ada koherensi antara ilmu pengetahuan dengan iman.

Dalam sejarah Islam, munculnya para filosof Muslim yang memiliki keilmuan yang intergratif seperti al-Farabi, seorang ahli medis, filosuf, seniman, sosiolog, ahli agama dan lain-lain. Ibn Sina, seorang ahli medis, ahli agama, filosof, matematika, logika dan lainnya. Ilmu kalam termasuk kajian pokok dan sentral. Ilmu ini termasuk rumpun ilmu ushuluddin. Begitu sentralnya kedudukan ilmu ini sehingga ia "mendominasi" arah, corak, muatan materi bahkan bisa dikatakan sebagai nahkodanya dalam sebuah kapal berlayar atau sebagai kompasnya pada metodologi kajian-kajian keislaman yang lain, seperti fikih, ushul fiqh, filsafah (Islam), 'ulüm al-tafsīr, 'ulūm al-hadìth, teori dan praktik dakwah dan pendidikan Islam, bahkan sampai merembet pada persoalanpersoalan yang terkait dengan pemikiran ekonomi dan politik Islam. Sedemikian kokoh dan pentingnya kedudukan ilmu kalam dalam studi-studi keislaman dan studi ilmu umum lainnnya.

Dalam rangka mengimplementasikan dan mengkomparasikan pemahaman antara semangat unity of sciences, yang sekarang ini menjadi paradigma keilmuan di UIN Walisongo, dengan mensinergikan ilmu-ilmu modern dalam bingkai transendensi dan perkembangan pemikiran dalam teologi Islam yang sekarang ini terpisah dari perkembangan science, maka teologi Islam akan menjadi dasar dan pijakan dari unity of sciences itu. Karena tawhìd dipahami dan diyakini sebagai penggambaran adanya unity of godhead yang akhirnya akan menghasilkan unity of creation atau kesatuan penciptaan.

Terkait dengan latar belakang masalah di atas, permasalahan yang akan dikaji dalam tulisan ini adalah bagaimana konstruksi teologi Islam dalam unity of sciences? Adapun tujuan penulisan ini adalah untuk mengetahui konstruksi teologi Islam dalam unity of sciences. Selanjutnya merekonstuksi teologi Islam dalam unity of sciences. Sedangkan manfaatnya dapat menemukan relevansi antara epistemologi unity of sciences yang berdasarkan teologi Islam sehingga 
menemukan sisi sisi transendensi yang ada dalam perkembangan keilmuan. Dengan demikian, kajian yang akan penulis bidik di sini adalah kalam atau teologi Islam yang merupakan sumber dari segala ilmu, baik imu keislaman maupun ilmu modern sehingga karena sumbernya satu maka ilmu tersebut bisa terintergrasi dan terkoneksi.

\section{B. Memahami Teologi Islam dan Unity of Sciences}

Teologi adalah hasil pemikiran yang bersumber pada keagamaan. Sebagai hasil pemikiran manusia, maka terbuka untuk diadakan verifikasi dan falsifikasi sesuai dengan dinamika sosial atau yang disebut dengan kontekstualisasi ajaran Islam. Oleh karena itu merekonstruksi teologi Islam klasik merupakan sebuah keniscayaan.

Dalam upaya merekonstruksi menuju sebuah format teologi yang dinamis perlu berdialog dengan realitas dan perkembangan pemikiran yang berjalan saat ini. Maka objek kajian ilmu teologi klasik yang bersifat transenden spekulatif ${ }^{4}$ harus diganti dengan kajian yang lebih aktual. Untuk melakukan rekonstruksi teologi, menurut Hassan Hanafi sekurang kurangnya dilatarbelakangi oleh tiga hal. Pertama, kebutuhan akan adanya sebuah ideologi yang jelas di tengah-tengah pertarungan global antara berbagai ideologi. Kedua, pentingnya teologi baru ini bukan semata pada sisi teoritisnya, melainkan juga terletak pada kepentingan praktis untuk secara nyata mewujudkan idiolagi sebagai gerakan dalam sejarah, salah satu kepentingan praktis ideologi Islam (dalam teologi) adalah memecahkan persoalan kemiskinan dan keterbelakangan negara Muslim. Ketiga, kepentingan teologi yang bersifat praktis, yaitu secara nyata diwujudkan dalam realitas melalui realisasi tawhīd dalam dunia Islam.

Konsekuensi perubahan teologi ini cukup dilematis. Satu sisi menjadi dinamis dan sisi yang lain adalah anti kemapanan yaitu corak agama selalu berubah. Teologi sebagai ilmu agama (ilmu tentang Tuhan) memiliki kesempatan untuk menciptakan sosial yang lebih baik, sehingga teologi dipahami secara lebih dialogis dan bertanggung jawab, maka pada persoalan ini lebih tepat dengan pendekatan integratif-interkonektifnya Amin Abdullah, sebagai upaya dekonstruksi atau merombak ulang untuk kemudian ditata kembali

${ }^{4}$ Hassan Hanafi, Dirasat Islamiyyah, (Kairo: Maktabah al-Anjilo al- Mishriyyah, t.th.), h. 205. 
frame berpikir masyarakat dalam melihat agama dalam relasinya dengan ilmu pengetahuan. ${ }^{5}$

Pada era teologi yang dipahami sebagai teosentris akan membuahkan paham keagamaan yang mandek. Sedang era teologi kontemporer menuntut teologi bisa dikaji dengan ilmu-ilmu interdisipliner. Idealnya teologi merupakan sumber dari munculnya beberapa ilmu pengetahuan. Sebab ilmu yang dihasilkan berdasarkan pemahaman atas tawhìd akan berbeda dengan ilmu yang dihasilkan melalui pemikiran ilmiah atau rasio yang sering melahirkan ilmu sekuler. Sedangkan unity of sciences mengidealkan adanya spiritualisasi dalam ilmu-ilmu modern atau menghumanisasi ilmu-ilmu keislaman. Dengan demikian penelitian ini merekrontruksi teologi Islam dalam unity of sciences, di mana teologi sebagai inspirator dalam ilmu-ilmu modern maupun ilmu keislaman.

Sains menjelaskan tentang apa dan bagaimana alam sebenarnya dan bagaimana teori ilmu pengetahuan dapat menjelaskan fenomena yang terjadi di alam. Untuk tujuan tersebut, sains menggunakan bukti dari eksperimen, deduksi logis, atau pemikiran rasional untuk mengamati alam dan individual dalam suatu masyarakat. Sedang Teologi sendiri adalah sebuah ilmu yang digulirkan untuk menetapkan ideologi-ideologi religius melalui dalil-dalil ideologis yakni pembangunan ideologi Islam berdasarkan atas asas rasionalisme demonstratif sehingga memungkinkan untuk memahami dan membela ideologi tersebut ${ }^{6}$. Oleh karena itu teologi dipandang sebagai sebuah pengetahuan metodis, sistematis dan koheren tentang seluruh kenyataan berdasarkan iman, sehingga arti sejati tawhìd adalah substansi dan asas Islam atau sebagai keyakinan induk.

Pada awalnya doktrin tawhìd kemudian menjadi sebuah teologi yang dikembangkan Nabi Muhammad berwatak dinamis, progresif dan liberatif. Tawhīd dipahami sebagai ajaran yang menyeru manusia hanya untuk menyembah kepada Allah, menghambakan diri kepada-Nya, menyerahkan totalitas eksistensial kemanusiaan kepada-Nya dan mengesakan-Nya dari segala bentuk penyembahan ketundukan, kepatuhan, penghambaan selainNya. Tawhïd itu berkarakter subversive, yakni menantang mainstream status quo dan memberontak terhadap segala struktur kuasa maupun sosial yang hegemonik, tiranik dan memberontak terhadap segala struktur kuasa maupun

${ }^{5}$ M. Amin Abdullah, Islamic Studies di Perguruan Tinggi ..., h. 92-93.

${ }^{6}$ Hassan Hanafi, Islamologi Teologi Statis ke Anarkis, (Yogyakarta: LKiS, 2007), h. 1. 
sosial yang hegemonik, tiranik dan sewenang-wenang. Doktrin tawhïd benarbenar revolusioner dan transformatif.

Namun seiring perkembangan zaman dan perjalanan sejarah dan perubahan peradaban, doktrin tawhìd mengalami pergeseran secara signifikan. Perbincangan teologi pada awalnya berkorelasi kuat dengan kenyataan aktual kemanusiaan, direduksi sedemikian rupa sehingga menjadi kumpulan wacana spekulatif yang jauh dari persoalan hidup.

Sebagai ilmu yang berdiri sendiri, teologi Islam belum dikenal pada masa Nabi, maupun pada masa sahabat. Akan tetapi barulahir di kala ilmu-ilmu keislaman satu persatu hadir dan banyak yang membicarakan tentang metafisika. Berkembangnya tradisi keilmuan baru yang sistematis dan formal serta spesialisasi bidang keilmuan, menyebabkan doktrin-doktrin tawhìd tertranformasi ke dalam bangunan doktrinal baku, tertutup teoritik dan kurang memiliki daya juang. Tawhịd hanya bergaung dalam karya para teolog Muslim atau Mutakallimin.

Sedangkan ruang lingkup Teologi Islam sebagai sebuah disipliplin ilmu, mempunyai objek kajian tentang ketuhanan dan segala sesuatu yang berkaitan dengan-Nya. Berkenaan dengan itu, maka teologi Islam membicarakan keyakinan kebenaran terhadap pengakuan eksistensi Tuhan beserta sifat-sifatNya dan segala sesuatu yang berhubungan dengan-Nya

Dengan demikian penegasan pemahaman mengenai paradigama unity of sciences atau yang bisa disebut waḥdat al-úlūm ini menegaskan bahwa semua ilmu, baik ilmu agama atau ilmu umum, pada dasarnya adalah satu kesatuan yang berasal dari dan bermuara pada Allah melalui wahyu-Nya, oleh karenanya semua ilmu sudah semestinya saling berdialog dan bermuara pada satu tujuan yakni mengantarkan pengkajinya semakin dekat kepada Allah. Demikian juga halnya teologi Islam atau yang dikenal dengan ilmu Kalam sebagai kajian ilmu yang berasal dari Allah dan memiliki keterikatan dan kesatuan dengan ilmuilmu yang lain, baik ilmu agama atau ilmu umum.

\section{Sains dan Teologi Sebuah Kesatuan dalam Memahami Tuhan}

Iman adalah sikap batin. Iman seseorang akan terwujud dalam sikap, perilaku dan perbuatannya, atau hasil karyanya terhadap sesamanya dan terhadap lingkungan hidupnya atau atas Tuhannya. Sebagai ilmu, teologi merefleksikan hubungan Allah dan manusia. Manusia berteologi karena ingin 
memahami imannya dengan cara lebih baik, dan ingin mempertanggungjawabkan bahwa "aku tahu kepada siapa aku percaya", karena teologi bukan agama dan tidak sama dengan ajaran Agama. Dalam teologi, adanya unsur "intellectus quaerens fidem" yaitu akal menyelidiki isi iman yang diharapkan memberi sumbangan substansial untuk integrasi antara akal dan iman, ilmu pengetahuan dan iman yang bertakwa, pada gilirannya sangat bermanfaat bagi hidup manusia masa kini dan yang akan datang.

Pandangan dikotomis terhadap ilmu pengetahuan tidak sesuai dengan pandangan integralistik ilmu pengetahuan pada permulaan sejarah umat Islam. Ternyata pandangan dikotomis yang menempatkan Islam sebagai suatu disiplin yang selama ini terasing dari disiplin ilmu lain telah menyebabkan ketertinggalan para ilmuwan Islam baik dalam mengembangkan wawasan keilmuan maupun untuk menyelesaikan masalah dengan multidimensional approach (pendekatan dari berbagai sudut pandang). Oleh karena itu wajarlah jika dikotomi ilmu pengetahuan mendapatkan gugatan dari masyarakat, termasuk gugatan dari para ilmuwan Muslim melalui wacana islamisasi ilmu pengetahuan. $^{7}$

Oleh karena itu ilmu pengetahuan Islam perlu direkonstruksi kembali dengan paradigma baru yaitu bahwa ilmu pengetahuan Islam menggambarkan terintegrasinya seluruh sistem ilmu pengetahuan dalam satu kerangka. Ilmu pengetahuan Islam menggunakan pendekatan wahyu, pendekatan filsafat, dan pendekatan empirik, baik dalam pembahasan substansi ilmu, maupun pembahasan tentang fungsi dan tujuan ilmu pengetahuan. Dengan rekonstruksi ilmu pengetahuan Islam tidak terkait lagi adanya dikotomi antara ilmu pengetahuan Islam maksudnya syari'ah, dengan ilmu pengetahuan umum, keduanya saling berhubungan secara fungsional (functional correlation). ${ }^{8}$

Dalam rangka menanggulangi persoalan di atas maka diperlukan adanya islamisasi ilmu pengetahuan dan juga dalam upaya merekonstruksi untuk menuju sebuah format teologi yang dapat berdialog dengan realitas dari perkembangan pemikiran yang berjalan pada waktu itu, maka objek kajian ilmu teologi klasik yang bersifat transenden-spekulatif yang relevansinya kurang jelas dengan kehidupan masa kini harus diganti dengan yang lebih

${ }^{7}$ Hassan Hanafi, Islamologi Teologi Statis ke Anarkis, h. 1.

${ }^{8}$ Hassan Hanafi, Islamologi Teologi Statis ke Anarkis, h. 119. 
aktual, dan perlu diupayakan pergeseran wilayah pemikiran ke arah paradigma pemikiran yang lebih menelaah dan mengkaji secara serius pada persoalan kemanusiaan.

Kondisi inilah yang memotivasi para cendekiawan Muslim berusaha keras dalam mengintegrasikan kembali ilmu dan agama. Upaya yang pertama kali diusulkan adalah islamisasi ilmu pengetahuan. Upaya "islamisasi ilmu" bagi kalangan Muslim yang telah lama tertinggal jauh dalam peradaban dunia moderen memiliki dilema tersendiri. Dilema tersebut adalah apakah akan membungkus sains Barat dengan label "Islami" atau "Islam"? Ataukah berupaya keras menstransformasikan normativitas agama, melalui rujukan utamanya al-Qur'an dan Hadits, ke dalam realitas kesejarahannya secara empirik? Kedua-duanya sama-sama sulit jika usahanya tidak dilandasi dengan berangkat dari dasar kritik epistemologis. Dari sebagian banyak cendikiawan Muslim yang pernah memperdebatkan tentang islamisasi ilmu, di antaranya adalah Ismail Raji al-Faruqi, Syed Muhammad Naquib al-Attas, Fazlur Rahman dan Ziauddin Sardar.

Kemunculan ide "islamisasi ilmu" tidak lepas dari ketimpangan-ketimpangan yang merupakan akibat langsung keterpisahan antara sains dan agama. Sekularisme telah membuat sains sangat jauh dari kemungkinan untuk didekati melalui kajian agama. Pemikiran kalangan yang mengusung ide "islamisasi ilmu" masih terkesan sporadis, dan belum terpadu menjadi sebuah pemikiran yang utuh. Akan tetapi, tema ini sejak kurun abad ke- 15 H., telah menjadi tema sentral di kalangan cendekiawan Muslim. Banyak pemikir intelektual Muslim mewacanakan rekonstruksi teologi Islam agar teologi Islam bisa menjadi ilmu tentang perjuangan sosial yang menjadikan keimanan tradisional memiliki fungsi secara aktual sebagai landasan etnik dan motivasi bagi manusia.

Secara umum islamisasi ilmu pengetahuan dimaksudkan untuk memberikan respon positif terhadap realitas ilmu pengetahuan modern yang sekularistik dan Islam yang terlalu relegius, ke dalam model pengetahuan baru yang utuh dan integral tanpa pemisahan. Adanya karakter yang sama dalam sains dan Islam seperti koherensi, komprehensip, kemanfaatan, dan kebenaran: (1) Sains dan Islam sama-sama dibentuk dan bergantung pada paradigma dan pada dasarnya ada kemungkinan untuk menyatukan paradigma sains dan Islam. (2) Adanya kesejajaran metodologis yang signifikan antara sains dan agama. (3) Adanya kesejajaran konseptual antara sains dan Islam. 
(4) Adanya saintis yang religius dan religius yang saintis. (5) Kuatnya anjuran wahyu untuk melakukan pengkajian yang menghasilkan ilmu. (6) Penafsiran sains dan agama sama-sama berasal dari pemahaman manusia sehingga bukanlah harga mati.

Dari berbagai referensi tentang pengertian islamisasi ilmu ditemukan beberapa versi, antara lain pertama, islamisasi ilmu hanya sekedar memberi label "Islam" pada ilmu pengertahuan. kedua islamisasi hanya mengislamkan orangnya. Ketiga islamisasi ilmu yang berdasarkan metodologi filsafat Islam. Keempat, islamisasi ilmu sebagai sebuah ilmu yang beretika atau beradab. ${ }^{9}$

Gagasan awal islamisasi ilmu pengetahuan ada sekitar 40 tahun yang lalu yaitu ketika ide tersebut digaungkan oleh Ismail Raji al-Faruqi dan Muhammad Naquib al-Attas juga Ziauddin Sardar. Gagasan ini merupakan respon atas dikhotomi ilmu agama dan sains yang dimasukkan Barat ke dunia Islam. Bagi al-Attas, islamisasi ilmu adalah pembebasan manusia dari tradisi magis, mitologis, animistis, dan belenggu paham sekuler. ${ }^{10}$ Baginya labelisasi Islam menjadi tidak penting jika virusnya belum dikeluarkan. Proses islamisasi ilmu pengetahuan harus disertai pemahaman formal dan keseluruhan nilai yang ditumbuhkan sejak dini.

Untuk melakukan islamisasi tersebut al-Attas melibatkan proses yang saling berhubungan. Pertama melakukan proses pemisahan elemen-elemen dan konsep-konsep kunci yang membentuk kebudayaan dan peradaban Barat. Kedua memasukkan elemen-elemen Islam dan konsep-konsep kunci ke dalam setiap cabang ilmu pengetahuan modern yang relevan. Sehingga gagasan islamisasi ilmu yang diformulasikan Syed Muhammad Naquib al-Attas merupakan suatu revolusi epistemologis yang merupakan merupakan jawaban terhadap krisis epistemologis yang melanda bukan hanya dunia Islam tapi juga budaya dan peradaban Barat.

Bagi al-Attas penyebab permasalahan keterpurukan umat Islam adalah bersumber dari kekeliruan persepsi keilmuan para pemimpin pada semua lapisan.Oleh al-Attas kekeliruan yang dilakukan pemimpin yang terus menerus menyebabkan ketiadaan $a d a b$ dari masyarakat yang akhirnya melahirkan

\footnotetext{
9Yusuf Amier Feisal, Reorientasi Pendidikan Islam, (Jakarta: Gema Insani Press,1995), h.30.

${ }^{12}$ Syed Muhammad Naquib al-Attas dalam Wan Moch Nor Wan Daud, The Educational Philosophy and Practice of Syed Muhammad Naquib al-Attas, ed. terjemah, (Bandung: Mizan,1998), h. 336.
} 
pemimpin yang tidak layak dan tidak berakhlaq yang luhur serta intelektual dan spiritualitas yang memadai. ${ }^{11}$

Konsep islamisasi ilmu pengetahuan yang ditawarkan al-Faruqi adalah melakukan penyaringan dari ilmu pengetahuan yang telah ada dengan mempertimbangkan nilai-nilai Islam. Atau menuang kembali teks-teks dari berbagai disiplin ilmu dengan wawasan ajaran Islam. ${ }^{12}$ Untuk melandingkan gagasannya ia meletakkan prinsip tawhìd sebagai kerangka pemikiran, metodologi dan cara hidup Islam, dengan cara kesatuan Tuhan, ciptaan, kebenaran, pengetahuan dan kemanusiaan.

Sebagai acuan untuk melandingkan islamisasi ilmu pengetahuan, al-Faruqi menggariskan satu kerangka kerja yaitu pertama, penguasaan disiplin ilmu modern. Kedua, penguasaan khazanah warisan Islam. Ketiga, membangun relevansi Islam dengan masing-masing disiplin ilmu modern. Keempat, memadukan nilai-nilai dan khazanah warisan Islam secara kreatif dengan ilmu modern. Kelima, pengarahan aliran pemikiran Islam ke jalan-jalan yang mencapai pemenuhan pola rencana Allah ${ }^{13}$

Upaya yang lainnya, yang merupakan antitesis dari usul yang pertama, adalah ilmuisasi Islam. Upaya ini diusung oleh Kuntowijoyo. Dia mengusulkan agar melakukan perumusan teori ilmu pengetahuan yang didasarkan kepada al-Qur'an, menjadikan al-Qur'an sebagai suatu paradigma. Upaya yang dilakukan adalah objektifikasi. Islam dijadikan sebagai suatu ilmu yang objektif, sehingga ajaran Islam yang terkandung dalam al-Qur'an dapat dirasakan oleh seluruh alam yang dalam bahasa al-Qur'an disebut raḥmatan li 'l-älamin, tidak hanya untuk umat Islam tetapi untuk semua orang juga bisa merasakan hasil dari objektifikasi ajaran Islam.

Masalah yang muncul kemudian adalah apakah integrasi tawhìd dengan ilmu-ilmu pengetahuan mungkin dilakukan dengan tetap tegak di atas prinsipprinsip tanpa mengacu pada pendekatan teologi normatif. Dalam pandangan Islam, alam semesta sebagai objek ilmu pengetahuan tidak netral, melainkan mengandung nilai (value) dan "maksud" yang luhur. Bila alam dikelola

\footnotetext{
${ }^{11}$ Syed Muhammad Naquib al-Attas dalam Wan Moch Nor Wan Daud, The Educational Philosophy and Practice..., h. 74.

${ }^{12}$ Rosnani Hasyim, Gagasan Islamisasi Kontemporer: Sejarah Perkembangan dan Arah Tujuan, (Jakarta: INSIST,2005), h. 29.

${ }^{13}$ Rosnani Hasyim, Gagasan Islamisasi Kontemporer..., h. 98.
} 
dengan "maksud" yang inheren dalam dirinya akan membawa manfaat bagi manusia. "Maksud" alam tersebut adalah suci atau baik sesuai dengan misi yang diemban dari Tuhan.

Ilmu pengetahuan adalah produk akal pikiran manusia sebagai hasil pemahaman atas fenomena di sekitarnya. Sebagai produk pikiran, maka corak ilmu yang dihasilkan akan diwarnai pula oleh corak pikiran yang digunakan dalam mengkaji fenomena yang diteliti. Dalam pandangan Islam, proses pencarian ilmu tidak hanya berputar-putar di sekitar rasio dan empirik, tetapi juga melibatkan al-qalbyakni intuisi batin yang suci. Rasio dan empirik mendeskripsikan fakta dan al-qalb memaknai fakta, sehingga analisis dan konklusi yang diberikan sarat makna atau nilai. Dalam pandangan Islam realitas itu tidak hanya realitas fisik tetapi juga ada realitas non-metafisis. Pandangan ini diakui oleh ontologi rasionalisme yang mengakui sejumlah kenyataan empiris, yakni empiris sensual, rasional, empiris etik dan empiris transenden..$^{14}$

Azyumardi Azra, mengemukakan ada tiga tipologi respon cendekiawan Muslim berkaitan dengan hubungan antara keilmuan agama dengan keilmuan umum. Pertama, restorasionis, yang mengatakan bahwa ilmu yang bermanfaat dan dibutuhkan adalah praktek agama maksudnya ibadah. Cendekiawan yang berpendapat seperti ini adalah Ibrahim Musa (w. 1398 M) dari Andalusia. Ibnu Taymiah, mengatakan bahwa ilmu itu hanya pengetahuan yang berasal dari nabi saja. Begitu juga Abu al-A'la Maududi, pemimpin jamaat al-Islam Pakistan, mengatakan ilmu-ilmu dari Barat, geografi, fisika, kimia, biologi, zoologi, geologi dan ilmu ekonomi adalah sumber kesesatan karena tanpa rujukan kepada Allah.

Kedua, rekonstruksionis interprestasi agama untuk memperbaiki hubungan peradaban modern dengan Islam. Mereka mengatakan bahwa Islam pada masa Nabi Muhammad dansahabat sangat revolutif, progresif, dan rasionalis. Sayyid Ahmad Khan (w. 1898 M) mengatakan firman Tuhan dan kebenaran ilmiah adalah sama-sama benar. Jamaluddin al-Afgani menyatakan bahwa Islam memiliki semangat ilmiah. Ketiga, reintegrasi, merupakan rekonstruksi ilmu-ilmu yang berasal dari al-āyāh al-qur'äniyyah dan yang berasal dari al$\bar{a} y a \bar{h}$ al-kawniyyah berarti kembali kepada kesatuan transendental semua ilmu pengetahuan. ${ }^{15}$

\footnotetext{
${ }^{14}$ Moh. Natsir Mahmud, Landasan Paradigma Islamisasi Ilmu Pengetahuan, Nurman Said, Wahyuddin Halim Muhammad Sabri (ed.), Jakarta: Gramedia, 1986), h. 129.

${ }_{15}$ Azyumardi Azra, "Reintegrasi Ilmu-ilmu dalam Islam", dalam Zainal Abidin Bagir (ed) Integrasi Ilmu dan Agama: Interprestasi dan Aksi, (Bandung: Mizan, 2005), h. 206- 211.
} 
Kuntowijoyo menyatakan bahwa inti dari integrasi adalah upaya menyatukan, bukan sekedar menggabungkan, wahyu Tuhan dan temuan pikiran manusia (ilmu-ilmu integralistik), tidak mengucilkan Tuhan (sekularisme) atau mengucilkan manusia (other worldly asceticism). ${ }^{16}$ Model integrasi adalah menjadikan al-Qur'an dan al-Sunnah sebagai grand theory pengetahuan. Sehingga ayat-ayat qawliyyah dan kawniyyah dapat dipakai.

Integrasi yang dimaksud di sini adalah berkaitan dengan usaha memadukan keilmuan umum dengan Islam tanpa harus menghilangkan keunikan antara dua keilmuan tersebut. Terdapat kritikan yang berkaitan dengan integrasi antara ilmu agama dan sains. Pertama, integrasi yang hanya cenderung mencocok-cocokkan ayat-ayat al-Qur'an secara dangkal dengan temuantemuan ilmiah. Di sinilah pentingnya integrasi konstruktif dimana integrasi yang menghasilkan kontribusi baru yang tidak diperoleh bila kedua ilmu tersebut terpisah. Atau bahkan integrasi diperlukan untuk menghindari dampak negatif yang mungkin muncul jika keduanya berjalan sendiri-sendiri, akan tetapi ada kelemahan dari integrasi, di mana adanya penaklukan, seperti teologi ditaklukkan oleh sains. ${ }^{17}$ Kedua, berkaitan dengan pembagian keilmuan, yaitu kawniyyah yang sering disebut dengan alam dan qawliyyah atau dimaknai teologis.

Kuntowijoyo mengatakan bahwa ilmu itu bukan hanya kawniyyah dan qawliyyah tetapi juga 'ilmu nafsiyyah. Kalau ilmu kawniyyah berkenaan dengan hukum alam, 'ilmu kawniyyah berkenaan dengan hukum Tuhan dan ilmu nafsiyyah berkenaan makna, nilai dan kesadaran. 'Ilmu nafsiyyah inilah yang disebut sebagai humaniora yaitu ilmu-ilmu kemanusiaan, hermeneutika. ${ }^{18}$

Amin Abdullah memandang, integrasi keilmuan mengalami kesulitan, yaitu kesulitan memadukan studi Islam dan umum yang kadang tidak saling akur karena keduanya ingin saling mengalahkan. Oleh karena itu, diperlukan usaha interkoneksitas yang lebih arif dan bijaksana. Interkoneksitas yang dimaksud oleh Amin Abdullah adalah Usaha memahami kompleksitas fenomena kehidupan yang dihadapi dan dijalani manusia. Sehingga setiap bangunan keilmuan apapun, baik keilmuan agama, keilmuan sosial, humaniora, maupun

\footnotetext{
16Kuntowijoyo, Islam sebagai Ilmu, cet. II, (Jakarta: Penerbit: Teraju, 2005), h. 25-26.

17Zainal Abidin Bagir, Integrasi Ilmu dan Agama ..., h. 50-51.

${ }^{18}$ Kuntowijoyo, Islam sebagai Ilmu, h. 51.
} 
kealaman tidak dapat berdiri sendiri, maka dibutuhkan kerjasama, saling tegur sapa, saling membutuhkan, saling koreksi dan saling keterhubungan antara disiplin keilmuan. ${ }^{19}$

Pendekatan integratif-interkonektif merupakan pendekatan yang tidak saling melumatkan dan peleburan antara keilmuan umum dan agama. Pendekatan keilmuan umum dan Islam sebenarnya dapat dibagi menjadi tiga corak yaitu: paralel, linear dan sirkular. Pendekatan paralel masing-masing corak keilmuan umum dan agama berjalan sendiri-sendiri tanpa ada hubungan dan persentuhan antara satu dengan yang lainnya. Pendekatan linear, salah satu dan keduanya akan menjadi primadona, sehingga ada kemungkinan berat sebelah. Sedangkan pola pendekatan sirkular, masing-masing corak keilmuan dapat memahami keterbatasan, kekurangan dan kelemahan pada masingmasing keilmuan dan sekaligus bersedia mengambil manfaat dari temuantemuan yang ditawarkan oleh tradisi keilmuan yang lain serta memiliki kemampuan untuk memperbaiki kekurangan yang melekat pada diri sendiri.20

Pendekatan integratif-interkonektif merupakan usaha untuk menjadikan sebuah keterhubungan antara keilmuan agama dan keilmuan umum. Muara dari pendekatan integratif-interkonektif menjadikan keilmuan mengalami proses objektivikasi di mana keilmuan tersebut dirasakan oleh orang yang bukan Muslim sebagai sesuatu yang natural (sewajarnya), tidak sebagai perbuatan keagamaan. Sekalipun demikian, dari sisi yang mempunyai perbuatan, bisa tetap menganggapnya sebagai perbuatan keagamaan, termasuk amal, sehingga Islam dapat menjadi rahmat bagi semua orang. ${ }^{21}$

Contoh konkret dari proses objektivikasi keilmuan Islam adalah ekonomi syari'ah yang prakteknya dan teori-teorinya berasal dari wahyu Tuhan. Islam menyediakan etika dalam perilaku ekonomi antara lain: bagi hasil yang disebut dengan al-mudarabah dan kerja sama atau yang lebih dikenal dengan almusyarakah. Di sini Islam mengalami objektivitas di mana etika agama menjadi ilmu yang bermanfaat bagi seluruh manusia, baik Muslim maupun yang bukan Muslim, bahkan arti agama sekalipun. Ke depan, pola kerja keilmuan yang integralistik dengan basis moralitas keagamaan yang humanistik dituntut

${ }^{19}$ M. Amin Abdullah, Islamic Studies di Perguruan Tinggi..., h. vii-viii.

${ }^{20}$ M. Amin Abdullah, Islamic Studies di Perguruan Tinggi ..., h. 219-223.

${ }^{21}$ Kuntowijoyo, Islam sebagai Ilmu, h. 62. 
dapat memasuki wilayah-wilayah yang lebih luas seperti: psikologi, sosiologi, antropologi, kesehatan, teknologi, ekonomi, politik, hubungan internasional, hukum dan peradilan dan seterusnya. ${ }^{22}$

Perbedaan pendekatan integrasi-interkoneksi dengan islamisasi ilmu adalah dalam hal hubungan antara keilmuan umum dengan keilmuan agama. Kalau menggunakan pendekatan islamisasi ilmu, maka terjadi pemilahan, peleburan dan pelumatan antara ilmu umum dengan ilmu agama. Sedangkan pendekatan integrasi interkoneksi lebih bersifat menghargai keilmuan umum yang sudah ada, karena keilmuan umum juga telah memiliki basis epistemologi, ontologi dan aksiologi yang mapan, sambil mencari letak persamaan, baik metode pendekatan atau approach dan metode berpikir yang disebut dengan procedure antar keilmuan dan memasukkan nilai-nilai keilmuan Islam ke dalamnya, sehingga keilmuan umum dan agama dapat saling bekerja sama tanpa saling mengalahkan. Dari pemaparan tersebut maka dapat diambil suatu kesimpulan bahwa dalam mengintegrasikan ilmu-ilmu keislaman ke dalam ilmu-ilmu umum sebaiknya mengacu kepada perspektif ontologis, epistemologis dan aksiologis.

Dari perspektif ontologis, bahwa ilmu itu pada hakikatnya, adalah merupakan pemahaman yang timbul dari hasil studi yang mendalam, sistematis, objektif dan menyeluruh tentang ayat-ayat Allah SWT. baik berupa ayat-ayat qauliyyah yang terhimpun di dalam al-Qur'an maupun ayat-ayat kawniyyah yang terhampar dijagat alam raya ini. Karena keterbatasan kemampuan manusia untuk mengkaji ayat-ayat tersebut, maka hasil kajian manusia tersebut harus dipahami atau diterima sebagai pengetahuan yang relatif kebenarannya, dan pengetahuan yang memiliki kebenaran mutlak hanya dimiliki oleh Allah.

Dari perspektif epistemologi, adalah bahwa ilmu pengetahuan dan teknologi diperoleh melalui usaha yang sungguh-sungguh dengan menggunakan instrumen penglihatan, pendengaran dan hati yang diciptakan Allah SWT. Terhadap hukum-hukum alam dan sosial yang sering disebut dengan Sunnatulläh. Karena itu tidak menafikan Tuhan sebagai sumber dari segala realitas termasuk ilmu pengetahuan dan teknologi.

22M. Amin Abdullah, Islamic Studies di Perguruan Tinggi ..., h. 105. 
Dari perspektif aksiologi, bahwa ilmu pengetahuan dan teknologi harus diarahkan kepada pemberian manfaat dan pemenuhan kebutuhan hidup umat manusia.Bukan sebaliknya, ilmu pengetahuan dan teknologi digunakan untuk menghancurkan kehidupan manusia. Perlu disadari bahwa ilmu pengetahuan dan teknologi adalah bagian dari ayat-ayat Allah dan merupakan amanat bagi pemiliknya yang nantinya akan dimintai pertanggung jawaban di sisi-Nya.

\section{Kesimpulan}

Berangkat dari pemaparan di atas bahwa struktur dan posisi tawhïd dalam ilmu pengetahuan yang dikembangkan Nabi Muhammad berwatak dinamis, progresif dan liberatif. Doktrin tawhïd benar-benar revolusioner dan transformatif. Akan tetapi seiring perkembangan zaman doktrin tawhïd mengalami pergeseran secara signifikan.Perbincangan teologi pada awalnya berkorelasi kuat dengan kenyataan aktual kemanusiaan, direduksi sedemikian rupa sehingga menjadi kumpulan wacana spekulatif yang jauh dari persoalan hidup dan gerak sejarah.

Teologi Islam sebagai sebuah disiplin ilmu keislaman, lahir pada abad ke-2 H./8 M. merupakan rumusan sistematis keprihatinan dan pergumulan pemikiran manusia tentang persoalan ketuhanan yang terjadi di pentas sejarah masa itu. Sehingga objek kajiannya, adalah berintikan pada masalah Tuhan, kumpulan diskursus keagamaan yang kosong, kering, kaku dan tidak punya kesinambungan dengan realitas kemanusian, sehingga tidak menyentuh pada persoalan kemanusiaan.

Rekonstruksi teologi Islam dalam unity of sciences dengan cara pendekatan integrasi-interkoneksi dan islamisasi ilmu pengetahuan. Pendekatan islamisasi ilmu pengetahuan adalah dengan cara pemilahan, peleburan dan pelumatan antara ilmu umum dengan ilmu agama. Sedangkan pendekatan integrasi interkoneksi lebih bersifat menghargai keilmuan umum yang sudah ada, karena keilmuan umum juga telah memiliki basis epistemologi, ontologi dan aksiologi yang mapan. Respon cendekiawan Muslim berkaitan hubungan antara ilmu pengetahuan Islam dan umum ada tiga tipologi, yaitu restorasionis, rekonstruksionis dan reintegrasi. Penyatuan antara ilmu-ilmu keislaman dengan ilmu-ilmu umum lebih condong kepada integrasi-interkoneksitas dan mengacu kepada perspektif ontologis, epistemologis dan aksiologis. 
Ilmu kalam atau teologi Islam yang hidup di era sekarang ini harus bisa berdialog dengan realitas dan perkembangan pemikiran yang berjalan saat ini, bukan dengan persoalan masa lalu, apalagi masa silam yang terlalu jauh.Telaah masa silam boleh saja sekekedar untuk memenuhi rasa kuriositas manusia. Teologi Islam kontemporer harus memahami perkembangan pemikiran manusia kontemporer yang diakibatkan oleh perubahan sosial yang dibawa oleh arus ilmu pengetahuan dan teknologi. Jika ilmu kalam klasik berdialog dengan pemikiran dan bergaul dengan format pemikiran serta epistemologi Yunani (Hellenisme), maka teologi Islam modern harus bersentuhan dengan pemikiran dan filsafat Barat modern yang dibentuk dan dilhami oleh arus perubahan yang diakibatkan oleh perkembangan ilmu pengetahun dan teknologi.[w] 


\section{BIBLIOGRAPHY}

Amin Abdullah, Islamic Studies di Perguruan Tinggi: Pendekatan IntegratifInterkonektif (Islamic Studies in Higher Education: Integrative-Interconnective Approach), Yogyakarta: Pustaka Pelajar, 2010.

al-Attas, Syed Muhammad Naquib, in Wan Moch Nor Wan Daud, The Educational Philosophy and Practice of Syed Muhammad Naquib al-Attas, Indonesian Edition, Bandung: Mizan,1998.

Azyumardi Azra, "Reintegrasi Ilmu-ilmu dalam Islam" (Reintegration of Sciences in Islam) in Zainal Abidin Bagir (eds) Integrasi Ilmu dan Agama, Interprestasi dan Aksi (Integration of Science and Religion, Interpretation and Action), Bandung: Mizan, 2005.

E. Kamadiningrat, Teologi dan Pembebasan: Gagasan Islam Kiri Hassan Hanafi (Theology and Liberation: Islamic Left Ideas of Hassan Hanafi), Jakarta: Logos, 1995.

Haryatmoko, Etika Politik dan Kekuasaan (Ethics of Politics and Power), Jakarta: Kompas, 2003.

Hassan Hanafi, Min al-'Aqìdah ilā Thaurah (From Aqidah to Revolution), Kairo: Maktabah Matbuli, 1991.

Hassan Hanafi, Islamologi Teologi Statis ke Anarkis (Statical Theology to Anarchic Islamology), Yogyakarta: LKiS 2007.

Kazuo Shimogaki, Kiri Islam Antara Modernisme dan Postmodernisme: Telaah Kritis Pemikiran Hassan Hanafi (Islamic Left between Modernity and Postmodernity: a Critical Thought of Hassan Hanafi), Yogyakarta: LKiS, 2001.

Kuntowijoyo, Islam sebagai Ilmu (Islam as Science), Jakarta: Teraju, 2005.

Madjid Fakhry, The History of Islamic Philosophy, New York: Columbia University Press, 1983.

Moh. Natsir Mahmud, Landasan Paradigma Islamisasi Ilmu Pengetahuan (The Paradigmatic Bases for Islamization of Sciences), Nurman Said, Wahyuddin Halim Muhammad Sabri, (eds.), Jakarta: Gramedia, 1986.

Rosnani Hasyim, Gagasan Islamisasi Kontemporer: Sejarah Perkembangan dan Arah Tujuan (The Ideas of Contemporary Islamization: History of Development and Destination), Jakarta: INSIST, 2005.

Walisongo, Volume 23, Nomor 2, November 2015 
Zainal Abidin Bagir, Integrasi Ilmu dan Agama (Integration of Science and Religion), Bandung: Mizan, 2005. 